\title{
Exploring the Impact of Attitude, Religiosity, Moral Obligation, Self-Efficacy and Subjective Norm on the Compliance Behavior of Income Zakat
}

Yusuf Haji-Othman, Mohd Sholeh Sheh Yusuff, Masri Azrul Nayan

To Link this Article: http://dx.doi.org/10.6007/IJARBSS/v11-i9/11199

DOI:10.6007/IJARBSS/v11-i9/11199

Received: 16 July 2021, Revised: 17 August 2021, Accepted: 03 September 2021

Published Online: 26 September 2021

In-Text Citation: (Haji-Othman et al., 2021)

To Cite this Article: Haji-Othman, Y., Yusuff, M. S. S., \& Nayan, M. A. (2021). Exploring the Impact of Attitude, Religiosity, Moral Obligation, Self-Efficacy, and Subjective Norm on the Compliance Behavior of Income Zakat. International Journal of Academic Research in Business and Social Sciences, 11(9), 1568-1578.

Copyright: @ 2021 The Author(s)

Published by Human Resource Management Academic Research Society (www.hrmars.com)

This article is published under the Creative Commons Attribution (CC BY 4.0) license. Anyone may reproduce, distribute, translate and create derivative works of this article (for both commercial and non-commercial purposes), subject to full attribution to the original publication and authors. The full terms of this license may be seen at: http://creativecommons.org/licences/by/4.0/legalcode

Vol. 11, No. 9, 2021, Pg. 1568 - 1578

Full Terms \& Conditions of access and use can be found at http://hrmars.com/index.php/pages/detail/publication-ethics 


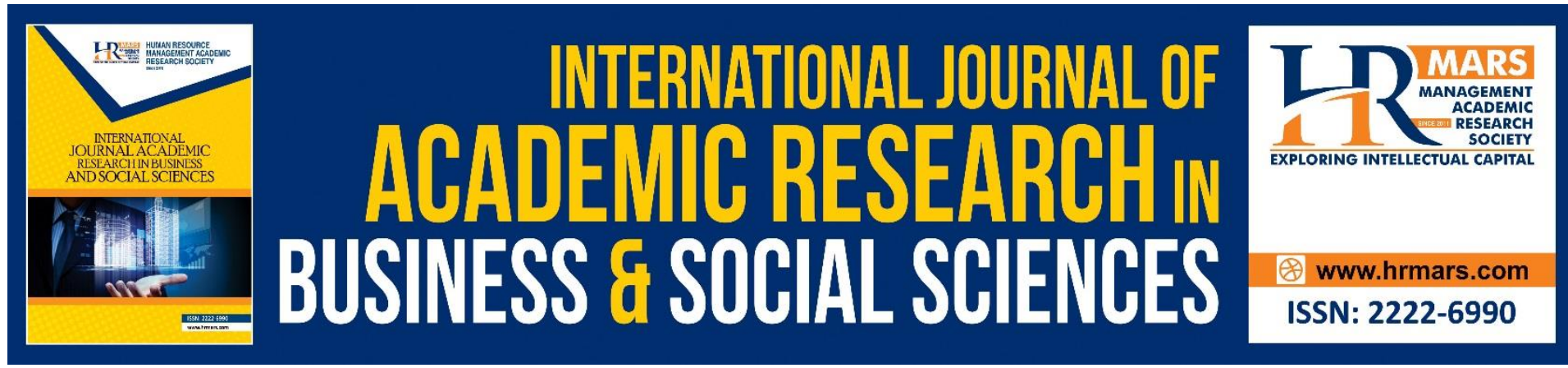

\title{
Exploring the Impact of Attitude, Religiosity, Moral Obligation, Self-Efficacy and Subjective Norm on the Compliance Behavior of Income Zakat
}

\author{
Yusuf Haji-Othman, Mohd Sholeh Sheh Yusuff, Masri Azrul \\ Nayan
}

Universiti Islam Antarabangsa Sultan Abdul Halim Mu'adzam Shah, Malaysia

\begin{abstract}
Despite a religious decree on the compulsory position of zakat on employment income in Malaysia, many Muslims still fail to fulfill their religious obligation to pay. Although there has been an increasing trend in the collection of business zakat, paddy zakat, and income zakat, there were some Muslims in Kedah who have not paid zakat to Kedah State Zakat Board (KSZB) so much so that the present increase in the collection of zakat is still not sufficient for distribution to all zakat recipients because of the increasing number of zakat asnaf. There is a rising trend in the collection of zakat. Yet, it is still insufficient to cover all zakat recipients, reflecting the efficiency (or the lack) of the Kedah State Zakat Board (KSZB) management. Studies on zakat compliance have shown mixed and inconclusive evidence regarding the determinants of income zakat compliance. Therefore, this study explores the impact of attitude, religiosity, moral obligation, self-efficacy, and subjective norm on the compliance behavior of income zakat in Kedah. This study employs the quantitative approach where this study collects primary data using questionnaires to determine significant determinants of compliance behavior of income zakat. This study reveals that attitude, religiosity, moral obligations, and self-efficacy are significant determinants of compliance behavior of income zakat in Kedah. However, this study finds that subjective norm does not significantly influence the compliance behavior of income zakat in Kedah. This study hopes to provide evidence that could be used as guidance for suitable policy and measures by Kedah State Zakat Board to improve zakat collection in the future.
\end{abstract}

Keywords: Attitude, Moral Obligation, Self-Efficacy, Zakat.

\section{Introduction}

The National Fatwa Council agreed upon a consensus on the 22nd June 1997 that income zakat is compulsory for every Muslim individual who has fulfilled the conditions of perfect title, nisab, and hawl (Abdul Aziz \& Abdullah, 2013). However, the zakat collection in Malaysia is still low, including income zakat. While most of the employees paid income tax which is a legal obligation, they did not comply with zakat payment which is a religious obligation (Saad et al., 2010; Bidin et al., 2009; Bidin \& Idris, 2009). 
Kedah, one of the states in Malaysia, gazette the compulsory zakat employment income on 19 April 1986 under section 38(2) of the Kedah Islamic Law of Administration 1962 of the Government Bill No. 146 (Tarimin, 1995). Yet, a study by Haji-Othman et al (2019) provides evidence that only 58 percent of Muslim workers paid salary zakat in Kedah. Despite a religious decree on the compulsory position of zakat on employment income in Malaysia, many Muslims still fail to fulfill their religious obligation to pay.

Although there has been an increasing trend in the collection of business zakat, paddy zakat, and income zakat, there were some Muslims in Kedah who have not paid zakat to Kedah State Zakat Board (KSZB) so much so that the present increase in the collection of zakat is still not sufficient for distribution to all zakat recipients because of the increasing number of zakat asnaf (Haji-Othman, 2017). There is a rising trend in the collection of zakat. Yet, it is still insufficient to cover all zakat recipients, reflecting the efficiency (or the lack of it) of the Kedah State Zakat Board (KSZB) management. Moreover, studies on zakat compliance have shown mixed and inconclusive evidence regarding the determinants of income zakat compliance. Therefore, this study reexamines the effects of attitude, religiosity, self-efficacy, and moral obligations on the compliance behavior of income zakat in Kedah. This study is hoped to provide evidence that could be used as guidance for suitable policy and measures by Kedah State Zakat Board to improve zakat collection in the future.

\section{Literature Review}

\section{Attitude and Compliance Behavior of Zakat}

There is voluminous literature that shows that attitude is a significant variable related to a particular behavior. Starting with Ajzen (1991), the study found some empirical evidence supporting the relationship between attitude towards behavior and intention to perform the behavior.

Sareye and Haji-Othman (2017) revealed that attitude and subjective norm have a positive and significant influence on intention towards paying zakat on business among single business owners at Kuala Ketil, Kedah. Also, attitude and perception towards law enforcement significantly influence the intention to comply with zakat on income (Farah et al., 2017). HajiOthman and Fisol (2017) revealed that attitude has significant relationships and a positive influence on intention.

Haji-Othman et al. (2017) also revealed that attitude significantly affects compliance behavior in pay income zakat among educators. Saad et al. (2010) also found that attitude played an essential role in influencing business zakat compliance behavior. Saad et al. (2008) found that the attitude and subjective norm played significant roles in influencing business zakat compliance.

\section{Religiosity and Compliance Behavior of Zakat}

There have been limited studies that have examined the influence of religiosity on zakat compliance. Haji-Othman, Yusuff \& Abd Latib (2018) proposed that religiosity, subjective norms, and perceived behavioral control influence compliance behavior.

Idris, Bidin \& Saad (2012) examined whether the Islamic religiosity measurement plays a significant role in the compliance behavior of zakat. The study used questionnaires as instruments with a sample size of 227 . The study concluded that the measurement of the 
component of religiosity has four dimensions. This study found that highly religious business owners are also more likely to comply with zakat law and that religiosity plays a significant role in zakat compliance behavior.

Haji-Othman et al (2017) provided evidence that Islamic religiosity significantly influences compliance behavior to pay employment income zakat. Haji-Othman, Alwi, et al. (2017) revealed that three variables explain the compliance behavior of income zakat: religiosity, subjective norms, and perceived behavioral control.

Islamic religiosity, however, did not show any significant influence on zakat compliance ( Farah et al., 2017). However, Zainol (2008) found that religiosity was an important factor that relates positively to zakat compliance behavioral intention.

\section{Moral Obligation and Compliance Behavior of Income Zakat}

Braithwaite et al (2006); Torgler (2004); Alm and Torgler (2006); Alm and Torgler (2011); Halla (2010) used moral obligation as an independent variable. On the other hand, Bobek and Hatfield (2003) used moral obligation as a moderating variable using TPB as the framework to study tax compliance behavior. The study revealed that when the moral obligation acts as a moderating variable in the Theory of Planned Behavior (TPB), it is a significant moderating variable to tax noncompliance. Haji-Othman (2016) revealed that moral obligation has a significant relationship and positive influences on intention. Haji-Othman et al. (2019) also showed that moral obligation is a significant determinant of intent to comply with income zakat payment.

\section{Self-Efficacy and Compliance Behavior of Zakat}

Self-efficacy refers to a person's belief about his/her ability to perform a particular behavior (Bandura, 1994). According to Bandura (1994), a person's self-efficacy can be developed through mastery experience, vicarious experiences provided by social models, social persuasion, and reduced stress reactions. Liu et al (2007) found that self-efficacy represented one of the dimensions of perceived behavioral control in the Theory of Planned Behavior (TPB). In the context of zakat compliance behavior, Bidin (2008) demonstrated that selfefficacy was a significant factor in zakat compliance behavioral intention. Saad (2010) supported this finding when the study substantiated that self-efficacy had a significant positive relationship with the intent to pay zakat. Haji-Othman and Nayan (2019) and HajiOthman, Sheh Yusuff, and Badrolhisham (2020) further reinforced this discovery when they found that self-efficacy was a significant determinant of zakat compliance behavior.

\section{Subjective Norms and Compliance Behavior}

Previous studies have received mixed empirical evidence supporting subjective norm as a significant determinant of intention to comply with zakat payment.

Zainol et al. (2009) exposed that subjective norms and attitudes had a positive and significant influence on behavioral intention. Zulkifli \& Sanep (2010) found that subjective norms significantly influenced zakat compliance behavior and supported this evidence. Nonetheless, Zainol, Mohd Zainudin, and Farah Mastura (2013) disputed this finding when they demonstrated that subjective norms had no significant influence on intention to comply with zakat on saving.

Zainol (2008) verified that a multi-dimensional subjective norm consisting of spouse, parents, and zakat amil was a significant factor related to zakat compliance behavioral intention. Ram 
Al Jaffri (2010), who reinforced the influence of spouse, peers, parents, and zakat amil, supported the finding on intention and compliance behavior of income zakat.

The studies so far have shown mixed findings regarding the influence of subjective norms on intention and compliance behavior. Although Ajzen (1991) postulates that subjective norms influence intention to perform a particular behavior, the evidence is still inconclusive, triggering further reexamination.

\section{Research Method}

This study uses a quantitative approach where primary data is collected using a questionnaire instrument. This quantitative method of this study can be classified as causal because this method examines the cause and effect relationship between variables in the study's theoretical framework.

\section{Theoretical Framework of the Study}

The theoretical framework is adapted and adopted from Ajzen (1991) and based on deductive reasoning. There are five independent variables: attitude, religiosity, moral obligation, selfefficacy, and subjective norm, while compliance is the dependent variable.

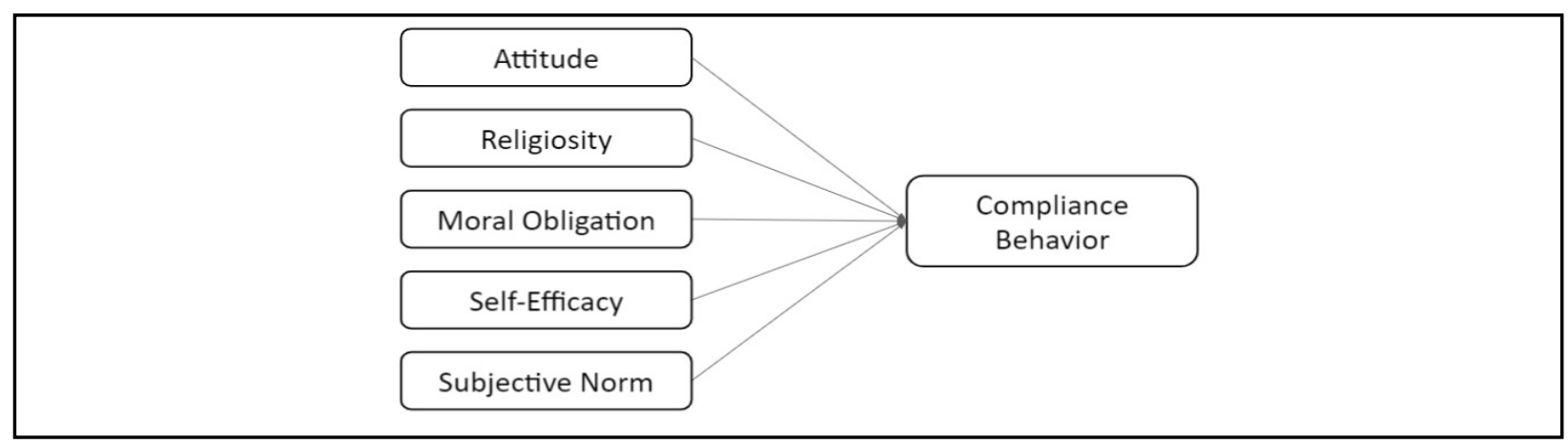

Figure 1. Theoretical Framework of the Study

\section{Data Collection}

This study uses a survey method using questionnaires to collect data. This method is appropriate because units of analysis (respondents) are distributed around the state of Kedah. This study population consists of public educators who are eligible to pay income zakat in Kedah, and the sample size used in this study is 372 .

\section{Data Analysis}

Data analysis of the study involves several stages. The first stage involves the assessment of the measurement model to identify the underlying structure of the variables involved (Hair, Hult, Ringle, and Sarstedt, 2014). In the second stage, the evaluation of the structural model is performed; that is, the data is run using the structural equation model (SEM). This study performs the measurement model using the validity factor analysis to validate the measurement scale (Hair et al., 2014). Variables that pass this analysis test are then applied to structural model analysis to examine the relationships between the endogenous variables and the exogenous variables of the study. 


\section{Findings and Discussions}

Table 1 reveals the finding of the study based on 372 randomly selected public educators in Kedah using structural equation modeling SMART PLS Version 3.

Table 1. The Effects of Attitude, Religiosity, Moral Obligation, Self-Efficacy, and Subjective Norm on Compliance Behavior of Income Zakat

\begin{tabular}{|l|c|c|}
\hline Path Relationship & t- Statistics & P Values \\
\hline Attitude -> Compliance Behavior & 5.814 & $\mathbf{0 . 0 0 0}$ \\
\hline Religiosity -> Compliance Behavior & 2.775 & $\mathbf{0 . 0 0 6}$ \\
\hline Moral Obligation -> Compliance Behavior & 2.979 & $\mathbf{0 . 0 0 3}$ \\
\hline Self-Efficacy -> Compliance Behavior & 2.483 & $\mathbf{0 . 0 1 3}$ \\
\hline Subjective Norm -> Compliance Behavior & 0.939 & $\mathbf{0 . 3 4 8}$ \\
\hline
\end{tabular}

This study reveals that attitude is a significant determinant of compliance behavior of income zakat in Kedah. This finding supports the findings of previous studies on compliance behavior of tax such as (Hite, 1988; Niemirowski, Baldwin \& Wearing, 2003; Ghosh and Crain, 1995; Kasipillai and Hijattullah, 2006; Marti, Wanjohi \& Magutu, 2010; Loo, MacKerchar \& Handsford, 2010; Natrah, 2011; Randlane, 2012; Trivedi, Shehata and Mestelman, 2005). Besides, this result conforms to studies on compliance behavior of zakat such as (Sapingi, Ahmad and Mohamad, 2011; Idris \& Ayob, 2002; Bidin, 2008; Bidin et al., 2009). This finding is important because, despite weak law enforcement on zakat compliance(Saad, 2010), attitude still plays a significant role in influencing intention to pay zakat. This discovery is contrary to Saad (2010) that attitude did not significantly affect intention to pay business zakat. The evidence indicates a difference between the attitude towards the zakat of Muslim business people and Muslim educators.

This finding supports Haji-Othman, Yusuff \& Abd Latib (2018); Haji-Othman (2017); HajiOthman et al (2019b); Furthermore, this finding supports Zainol (2008); Zainol et al (2009), who demonstrated that attitude positively influenced intention to pay income zakat. This finding supports the Theory of Planned Behavior's expectation that attitude plays a significant influence on intention to perform a particular behavior, which reaffirms the significance of TPB in predicting compliance behavior. The voluminous literature on TPB has focused on tax compliance behavior, which has strong tax laws and law enforcement, and proved that attitude significantly influenced intention. On the other hand, this study examines the compliance behavior of income zakat in Kedah, which has weak law and enforcement (Saad, 2010), yet still proves that attitude plays a significant role in influencing intention. This discovery is due to the selection of respondents who are Muslim educators. Educators, being persons responsible for educating others, should have suitable attitude dimensions such as agreeing and supporting attitude. These dimensions of agreeing and supporting attitude should trigger their intention to pay employment income zakat despite the weak law and law enforcement on zakat in Kedah.

In addition, this study reveals that Islamic religiosity plays a significant role in influencing the compliance behavior of income zakat in Kedah. This finding implies that Islamic religiosity is one of the most significant determinants determining whether Muslim educators pay income zakat or not to Kedah State Zakat Board (KSZB). The higher the religiosity of the Muslim 
educators, the more likely they will pay income zakat. The law and law enforcement regarding the payment of income zakat in Kedah is still low. Therefore, KSZB still depends on the religiosity factor and employs persuasion using religious sentiments to encourage zakat payers to perform their duty of paying income zakat.

Furthermore, this study reveals that moral obligation significantly influences the compliance behavior of income zakat in Kedah. This finding implies that a person with a high moral obligation is more likely to pay income zakat. This evidence is consistent with Braithwaite, Reinhart and Smart (2006); Halla (2010); Kirchler et al (2007), who found that moral obligation significantly influenced tax compliance. It is worth mentioning that moral responsibility or obligation depends on ethics, which is one's belief about right and wrong (Alm and Torgler, 2011). In the context of income zakat, a Muslim having a moral obligation has an intrinsic motivation to pay zakat because doing so is the ethical thing to do, which would end up helping other Muslims. Although there may be a commonality between moral obligation and Islamic religiosity, the two are distinctly different because, first of all, not all Muslims are religious. Religiosity varies across all individual Muslims, just as morality varies across individuals. Even atheists could be highly moral individuals. Thus, it is also possible that not so religious Muslims could be highly moral Muslims, and vice versa. This study is able to provide evidence that even in the case of religious obligations such as zakat, morality and ethics play a significant role.

In addition, this study revealed that self-efficacy is a significant determinant of compliance behavior of income zakat. This study verifies self-efficacy, which Bandura (1994) defined as a person's belief about his/her ability to perform a particular behavior to significantly influence compliance behavior of income zakat even in the setting of employment income zakat. It indicates that the respondents who have high self-efficacy are more likely to comply with employment income zakat payment. This finding conforms with Bidin's (2008) findings, who ascertained that self-efficacy was a significant factor in zakat compliance behavioral intention. Saad (2010) supported this evidence when the study revealed that self-efficacy had a significant positive relationship with intention.

However, this study provides evidence that subjective norm does not have any significant relationship with the compliance behavior of income zakat. This evidence is consistent with the findings by Al Jaffri (2010). Similarly, Ajzen (1991) also reported that 9 out of 16 studies using TPB evidenced a nonsignificant relationship between subjective norm and intention. However, this finding contradicts Zainol et al. (2009), who discovered that subjective norm had a significant positive relationship with intention. There are voluminous studies that support a positive and significant relationship between subjective norm and intention in the context of compliance behavior of tax such as (Bobek and Hatfield 2003; Bobek, Roberts and Sweeney, 2007; Davis, Hecht and Perkins, 2003; Faa, 2008; Rizal, 2010).

In the context of compliance behavior of employment income zakat, the insignificant relationship between subjective norm and intention is justifiable. It indicates that their intimate group does not influence Muslim public educators' compliance behavior of income zakat, learned group, and peer group. They would still comply with employment income zakat payment even though these intimate groups, the learned group, and the peer group do not influence them. 
The influence of these intimate groups, learned groups, and peer groups on the compliance behavior of income zakat is not significant because the actual non-compliant zakat behavior is not visible, and therefore not observable. Whether a Muslim pays income zakat or not is not noticeable by these intimate, learned, and peer groups. In other words, these groups are unaware of any compliant or non-compliant activities undertaken by the individual Muslim. The compliant or non-compliant activities must be visible or known to these groups to have a significant influence. The outcome of an insignificant relationship between subjective norm and intention towards zakat compliance is supported by (Saad, 2010).

Furthermore, as Kamil (2002) suggested, the learned religious group preferred to pay zakat directly to the recipients rather than to zakat institutions. If this is so, the learned religious group could not influence their intention to pay employment income zakat to Kedah State Zakat Board.

\section{Conclusion}

Zakat is an essential Islamic social finance instrument that could finance specific programs to achieve social, political, and economic development among Muslim communities. However, the issue which arises is that zakat collection, including income zakat, is still low, which hinders the effectiveness of zakat in playing a more significant role in the state of Kedah. This study explores the impact of attitude, religiosity, moral obligation, self-efficacy, and subjective norm on the compliance behavior of income zakat. This study provides empirical evidence that attitude, religiosity, moral obligation, and self-efficacy are significant determinants of compliance behavior of income zakat in Kedah. However, this study discloses that subjective norm does not have any significant relationship with the compliance behavior of income zakat. This study recommends that future studies on zakat compliance use other methods such as interviews to obtain more in-depth information about determinants of zakat compliance. This study focuses on Kedah, a part of Malaysia, which has a zakat institution under the administration of the State Islamic Religious Council. Therefore, this study recommends that future studies explore the compliance behavior of zakat in other countries where the governments have not established zakat institutions under the law. Nonetheless, this study is hoped to provide evidence that could guide suitable policy and actions by the Kedah State Zakat Board to improve zakat collection strategies in the future.

\section{References}

Abdul Aziz, M. A., \& Abdullah, M. H. (2013). The Comparison between Zakat (Islamic Concept of Taxation) and Income Tax: Perceptions of Academician in the State of Perak, Malaysia. The 2013 IBEA, International Conference on Business, Economics, and Accounting, March.

Ajzen, I. (1991). The Theory of Planned Behavior. Organizational Behavior and Human Decision Processes, 50, 179-211.

Alm, J., \& Torgler, B. (2006). Culture Differences and Tax Morale in the United States and in Europe. Journal of Economic Psychology, 27, 224-246.

https://doi.org/10.1016/j.joep.2005.09.002

Alm, J., \& Torgler, B. (2011). Do Ethics Matter? Tax Compliance and Morality. Journal of Business Ethics, 101(4), 635-651. https://doi.org/10.1007/s10551-011-0761-9

Bandura, A. (1994). Self-Efficacy. In Encyclopedia of Human Behavior (Issue 1994, pp. 1-65).

Bidin, Z. (2008). Faktor-faktor Penentu Niat Gelagat Kepatuhan Zakat Pendapatan Gaji. 
Bidin, Z., \& Idris, M. K. (2009). Sikap, Norma Subjektif dan Kawalan Gelagat Ditanggap terhadap Niat Gelagat Kepatuhan Zakat Pendapatan Gaji. IJMS, 16(1), 31-55.

Bidin, Z., Idris, M. K., \& Shamsudin, M. F. (2009). Predicting Compliance Intention on Zakah on Employment Income in Malaysia: An Application of Reasoned Action Theory. Jurnal Pengurusan, 28, 85-102.

Bobek, D. D., \& Hatfield, R. C. (2003). An Investigation of the Theory of Planned Behavior and the Role of Moral Obligation in Tax Compliance. Behavioral Research in Accounting, 15, 13-38.

Bobek, D. D., Roberts, R. W., \& Sweeney, J. T. (2007). The Social Norms of Tax Compliance: Evidence from Australia, Singapore, and the United States. Journal of Business Ethics, 74(1), 49-64. https://doi.org/10.1007/s10551-006-9219-x

Braithwaite, V., Reinhart, M., \& Smart, M. (2006). Tax Non-Compliance among the Under-30s (Issue c, pp. 256-280).

Davis, J. S., Hecht, G., \& Perkins, J. D. (2003). Social Behaviors, Enforcement, and Tax Compliance Dynamics. The Accounting Review, 78(1), 39-69.

https://doi.org/10.2308/accr.2003.78.1.39

Faa, S. G. (2008). Tax Compliance Behavior of Individuals Under Self Assessment System.

Ghosh, D., \& Crain, T. L. (1995). Ethical Standards, Attitudes Toward Risk, and Intentional Noncompliance: An experimental Investigation. Journal of Business Ethics, 14(5), 353365. https://doi.org/10.1007/BF00872098

Hair, J. F., Hult, G. T. M., Ringle, C. M., \& Sarstedt, M. (2014). A Primer on Partial Least Squares Structural Equation Modelling (PLS-SEM). SAGE Publications.

Haji-Othman, Y. (2017). Compliance Behavior of Income Zakat in Kedah: A Moderating Effect of Islamic Religiosity. Sultan Abdul Halim Mu'adzam Shah International Islamic University.

Haji-Othman, Y., Alwi, I., Yusuff, S. M. S., \& Saufi, M. S. A. (2017). The Influence of Attitude, Subjective Norm, and Islamic Religiosity on Compliance Behavior of Income Zakat Among Educators. International Journal of Academic Research in Business and Social Sciences, 7(11), 1110-1116.

Haji-Othman, Y., Cheumar, M., Abdullah, N., \& Dorloh, S. (2020). The Effects of Attitude, Religiosity and Moral Obligation on Compliance Behavior of Income Zakat in Kedah, Malaysia. 2020(October), 1-7.

Haji-Othman, Y., \& Fisol, M. W. N. (2017). Islamic Religiosity, Attitude and Moral Obligation on Intention of Income Zakat Compliance: Evidence from Public Educators in Kedah. Journal of Academic Research in Business ..., 7(2), 726-737. https://doi.org/10.6007/IJARBSS/v7-i2/2680

Haji-Othman, Y., Fisol, M. W. N., \& Yusuff, S. M. S. (2019a). Income Zakat: Issues, Concepts, Management, Discussions and Suggestion. Lambert Academic Publishing.

Haji-Othman, Y., Fisol, M. W. N., \& Yusuff, S. M. S. (2019b). Income Zakat: Issues, Management and Suggestions. UniSHAMS.

Haji-Othman, Y., \& Nayan, M. A. (2019). the Influence of Perception Towards Promotion and Self-Efficacy on Intention and Compliance Behavior of Income Zakat in Kedah, Malaysia. 2(2011), 30-41.

Haji-Othman, Y., Nazjmi, W., Fisol, M., \& Faisal, M. (2019). Motivations for Paying Income Zakat and Relations To Maqasid Shari'ah and Sustainable Development Goals. 2019(June 1997), 410-421.

Haji-Othman, Y., Yusuff, S. M. S., \& Abd Latib, M. F. (2018). Motivations for Paying Income 
Zakat among UniSHAMS' Employees. International Journal of Academic Research in Business and Social Sciences, 8(10), 619-628. https://doi.org/10.6007/IJARBSS/v8$\mathrm{i} 10 / 4768$

Haji-Othman, Y., Sheh Yusuff, M. S., \& Badrolhisham, N. (2020). The Effects of Perception Towards Promotional Exposure, Self-Efficacy, and Perception Towards Equity in Zakat Distribution on Compliance Behavior of Income Zakat in Kedah, Malaysia. International Journal of Muamalat, 4(1), 10-16.

Haji-Othman, Y., Yusuff, S. M. S., Saufi, M. S. A., \& Al-Habshi, S. H. (2017). The Influence of Knowledge, Islamic Religiosity and Self- Efficacy on the Intention to Pay Income Zakat among Public Educators in Kedah, Malaysia. International Journal of Academic Research in Business and Social Sciences, 7(11), 1117-1127. https://doi.org/10.6007/IJARBSS/v7i11/3550

Halla, M. (2010a). First Evidence on a Causal Link Tax Morale and Compliance Behavior: First Evidence on a Causal Link (Issue 4918).

Halla, M. (2010b). The Link between the Intrinsic Motivation to The Link between the Intrinsic Motivation to Comply and Compliance Behavior : A Critical Appraisal of Existing Evidence. 4843.

Hite, P. A. (1988). The Effect of Peer Reporting Behavior on Taxpayer Compliance. The Journal of the American Taxation Association, 47-64.

Kirchler, E., Muehlbacher, S., Kastlunger, S., \& Wahl, I. (2007). Why Pay Taxes? A Review of Tax Compliance Decisions. In International Studies Program Working Paper, Georgia State University (Vols. 07-30, Issue December 2007). https://doi.org/10.4324/9780203851616

Liu, Y., Doucette, W. R., \& Farris, K. B. (2007). Perceived Difficulty and Self-efficacy in the Factor Structure of Perceived Behavioral Control to Seek Drug Information from Physicians and Pharmacists. Research in Social and Administrative Pharmacy, 3(2), 145159. https://doi.org/10.1016/j.sapharm.2006.07.002

Idris, M. K., \& Ayob, A. M. (2002). Peranan Sikap dalam Gelagat Kepatuhan Pendapatan Gaji. Analisis, 9, 171-191.

Idris, M. K., Bidin, Z., \& Saad, R. A. J. (2012). Islamic Religiosity Measurement and its Relationship with Business Income Zakat Compliance Behavior. Jurnal Pengurusan, 34, 3-10.

Farah, M. S. J., Haji-Othman, Y., \& Omar, M. (2017). The Influence of Attitude, Religiosity, and Perception towards Law Enforcement on Intention towards Compliance Behaviour of Income Zakat among KUIN Staff in Kedah, Malaysia. International Journal of Muamalat, 1(1), 25-45.

Sareye, M. J., \& Haji-Othman, Y. (2017). The Influence of Attitude, Subjective Norms and Service Quality on Intention to Pay Business Zakat Among Single Business Owners at Kuala Ketil, Malaysia. International Journal of Novel Research in Humanity and Social Sciences, 4(1), 100-107.

Rizal, M. P. (2010). Tax Knowledge and Tax Compliance Determinants in Self Assessment System in Malaysia.

Natrah, S. (2011). Fairnes, Perceptions and Compliance Behavior: Taxpayers' Judgements in Self-assessment Environments.

Niemirowski, P., Baldwin, S., \& Wearing, A. J. (2003). Tax Related Behaviours, Beliefs, Attitudes and Values and Taxpayer Compliance in Australia. Journal of Australian Taxation, 6(1), 132-165. 
Saad, R. A. J. (2010). Gelagat Kepatuhan Zakat Perniagaan di Negeri Kedah Darul Aman.

Saad, R. A. J., Bidin, Z., Idris, M. K., \& Hussain, M. H. (2010). Faktor-Faktor yang Mempengaruhi Gelagat Kepatuhan Zakat Perniagaan. Jurnal Pengurusan, 30, 49-61.

Sapingi, R., Ahmad, N., \& Mohamad, M. (2011). A Study on Zakah of Employment Income: Factors that Influence Academics' Intention to Pay Zakah. 2nd International Conference on Business and Economic Research, 2492-2507.

Tarimin, M. (1995). Zakat Penggajian: Satu Penilaian Terbaru di Malaysia. Universiti Malaya.

Torgler, B. (2004). Cross-Culture Comparison of Tax Morale and Tax Compliance: Evidence from Costa Rica and Switzerland. International Journal of Comparative Sociology, 45(12), 17-43. https://doi.org/10.1177/0020715204048309

Zainol, B., Zainudin, M. O., \& Mastura, F. N. A. (2013). Zakat Compliance Intention Behavior on Saving among Universiti Utara Malaysia's Staff. Proceeding of the International Conference on Social Science Research, Penang Malaysia, June 2013, 145-155. https://doi.org/OYA Graduate School of Business

Zulkifli, D., \& Sanep, A. (2010). Kesan Perundangan Zakat ke atas Kepatuhan Bayaran Zakat: Ke arah Strategi Berkesan Program Pengurusan Kutipan Zakat. The 4th ISDEV International Islamic Development Management Conference (IDMAC 2010), December, 1-17. 